Katarina Dimšić

DOI: https://dx.doi.org/10.21857/m3v76tej7y

Izlaganje sa znanstvenog skupa

Rukopis prihvaćen za tisak: 21.12.2020.

\title{
PETAR BOGDEŠIĆ (1863. - 1934.) - SLAVONSKI UČITELJ I ZAPISIVAČ ETNOGRAFSKE I FOLKLORISTIČKE GRAĐE
}

\begin{abstract}
Sažetak
U radu se, na temelju analize dostupnih biografskih podataka o Petru Bogdešiću i njegove suradnje s nacionalnim institucijama na prikupljanju etnografskih i folklorističkih zapisa te njegova sudjelovanja u kulturnim i društvenim događanjima u mjestima u kojima je službovao kao učitelj od 1882. godine do umirovljenja 1924. godine (Dragovci, Brod na Savi, Krapina), nastoji osvijetliti činjenica da su učitelji kao prosvjetni djelatnici angažirano sudjelovali u procesu oblikovanja i jačanja nacionalnog identiteta. Taj se angažman iskazao u bilježenju materijalne, nematerijalne i duhovne kulture hrvatskoga sela na temelju naputaka te u suradnji s urednicima izdanja u kojima se prikupljena građa objavljivala. Biografski podatci o Petru Bogdešiću kao učitelju i angažiranom prosvjetnom i kulturnom djelatniku rekonstruirani su na temelju istraživanja dostupnih izvora, a njegov etnografski i folkloristički rad na temelju komparativne analize dvaju rukopisa koji se čuvaju u arhivu Odsjeka za etnologiju Hrvatske akademije znanosti i umjetnosti u Zagrebu.
\end{abstract}

Ključne riječi: Petar Bogdešić; učitelj; Dragovci; Brod na Savi; etnografski zapisi; narodne pjesme.

\section{Uvodno o Petru Bogdešiću}

Petar Bogdešić rodio se 26. lipnja 1863. u Vrbovi kod Požege na starom kućnom broju 40 (prilog 1). Petrova majka Marija umrla je kada je on imao nepunih šest godina. Odgojio ga je otac Mato, koji ga je - kako sam navodi u zapisima - školovao, naučio radu, marljivosti i snalažljivosti. ${ }^{1}$ Učiteljsku školu u tadašnjem centru pedagoškog obrazovanja - Petrinji - završio je 1882. godine (usp. Božić, 1952: 44). Dekretom Kraljevske zemaljske vlade, Odjela za bogoštovlje i nastavu, imenovan je 1882. godine privremenim, a 1884. godine "pravim učiteljem obće pučke škole“ u

\footnotetext{
U svojem je rukopisu manji dio Bogdešić posvetio i svojem ocu, kojeg je opisao kao marljivog, spretnog i obiteljskog čovjeka (usp. Bogdešić (1899), SZ 92, str. 4)
} 
mjestu Dragovci, gdje je službovao ukupno devet godina. ${ }^{2}$ Kratko vrijeme djelovao je u (Starom) Petrovu Selu, a 1892. godine dobio je premještaj u Brod na Savi. U to je vrijeme bio i polaznik Pomološko-enološkog zavoda Više voćarsko-vinogradarske škole u Klosterneuburgu kraj Beča u Austriji. ${ }^{3}$

Nedugo nakon doseljenja upoznao je i svoju buduću suprugu - oženio se 9. veljače 1893. Marijom Maričević. ${ }^{4}$ Iste godine dobili su kćer Mariju Zdenku, koja je sa svega nekoliko mjeseci umrla, ${ }^{5}$ a krajem 1894. godine rodio im se sin Branimir Tomislav. Bio je odličan učenik Više tehničke škole. Kao osmogodišnjak prebolio je šarlah, a umro je od tuberkuloze u 21. godini života. ${ }^{6}$ Bogdešićeva kći Ivana rođena je oko 1898. godine. Kao dugogodišnja članica Hrvatskog dobrotvornog gospojinskog društva u Brodu, sudjelovala je u predstavama i drugim programima Društva te je, poput svojeg oca, svirala tamburu. U Društvu je upoznala i svojega budućeg supruga Jozu Pilara ${ }^{7}$, s kojim je dobila kćer Branku. Neko su vrijeme živjeli u Požegi, kasnije u Zagrebu. ${ }^{8}$ Zanimljivo je napomenuti da je 1921. godine Bogdešić osnovao Zakladu Matice hrvatske koja je nosila ime njegove djece:

„Slavno predsjedničtvo! Šaljem Vam 15.000 (petnajst hiljada) Kruna, a da od njih sačinite zakladu pod naslovom: 'Zaklada Branimira i Ivane Bogdešić', od koje kamatama imala bi se nagrađivati djela izašla nakladom 'Matice Hrvatske' (...). Koju vrst književnosti da se podupre, prepuštam Vama. ${ }^{\prime 9}$

Svrha zaklade bilo je poticanje hrvatskog književnog i kulturno-umjetničkog stvaralaštva.

Petar Bogdešić od 1897. godine na službi je u Višoj pučkoj školi u Krapini, ali je na kraju školske godine 1901./02. vraćen u Brod na Savi, gdje je ostao do svoje smrti. Umro je u 71. godini života, 30. siječnja 1934., od posljedica moždanog udara.

Učiteljski stalež kojemu je pripadao Bogdešić imao je veliku ulogu u izgradnji nacionalnog identiteta kroz obrazovne procese. Često su ti procesi bili zahtjevni,

2 Službeni glasnik kr. hrv.-slav.-dalm. Zemaljske vlade odjela za bogoštovje i nastavu, godina 1884., str. 137.

3 Službeni glasnik kr. hrv.-slav.-dalm. Zemaljske vlade odjela za bogoštovje i nastavu, godina 1892., str. 242.

4 Svjedoci na vjenčanju bili su Bogdešićevi kolege - Bude Banjeglav i Pero Rogović. Sva trojica, Bogdešić, Banjeglav i Rogović, iste su godine došli u Višu pučku školu u Brodu na službu (usp. Izvještaj više pučke škole realnog smjera is njim spojene dječačke, te šegrtske škole u Brodu na Savi koncem 1902.-1903. (1903), str. 15).

5 Matica umrlih Rimokatolička od 1875-1894. Slavonski Brod.

6 Usp. Izvještaj više pučke škole realnog smjera is njim spojene dječačke, te šegrtske škole u Brodu na Savi koncem 1902.-1903. (1903.), str. 67; Učiteljski zbor Pučke škole Krapina, zapisnik sa sjednice 4. 1. 1902. (1902).

7 Jozo je bio blagajnik Društva te jedan od osnivača Građanskog športskog društva Marsonija u Brodu na Savi (usp. Katalinić, 1934: 23). Manje je poznato da je bio nećak geologa Đure Pilara i bratić Ive Pilara (usp. Jonjić, 2015: 62).

8 Usp. Državni arhiv Slavonski Brod: Spomenica Hrvatskog dobrotvornog gospojinskog društva u Slavonskom Brodu (1935).

9 HR-HDA-1567. Matica hrvatska (MH). Zaklade. Zakladni list 20, kut. 80. 
ponajviše zbog otežanih uvjeta rada te uslijed čestih premještaja. O sličnom stanju posvjedočio je i sam Bogdešić 1901. godine za vrijeme učiteljevanja u Krapini:

„Potpisano učiteljstvo već duže vremena promatra svoj kukavni materijalni položaj. Od godine u godinu nada se boljemu, ali čim dulje kuburi, tim mu je gore i teže. (...) Što će dakle u svojoj nevolji, u svome stradanju? Zar zdvojiti? To nipošto jer previše voli povjerenu si dječicu, kojoj utire dobar put k sretnomu ovom i onozemnu životu. ${ }^{\text {"10 }}$

Iako su plaće bile male i uvjeti rada zahtjevni, učitelji su svoj posao obavljali s mnogo ljubavi i s ciljem kvalitetnog odgoja svojih učenika. Osim toga, sudjelovali su u društvenim događanjima i bili pokretači raznih događaja:

„Društveni život učitelja bio je vrlo angažiran. Učitelji su inicijatori i aktivni sudionici humanitarnih akcija, kulturnih zbivanja, rada u različitim udrugama. Kao obrazovani ljudi, posebno u malim sredinama, učitelji su doista bili promicatelji naprednih ideja." (Batinić, Gaćina Škalamera, 2009: 81)

U idućem poglavlju pokazat će se kako je i Petar Bogdešić bio jedan od aktivnih sudionika kulturnih i društvenih događanja u mjestima u kojima je bio u službi.

\section{Petar Bogdešić - učitelj i kulturni djelatnik}

Nakon dolaska u Brod Bogdešić se uključio u Hrvatsko pjevačko društvo „Davor", čiji je predsjednik od 1894. bio Vatroslav Brlić iz poznate brodske obitelji Brlić. Članovi uprave i Odbora bili su redom pripadnici brodske građanske elite. ${ }^{11}$ Građanske obitelji poput Brlića i drugih obitelji i pojedinaca, Bogdešićevih suvremenika, imale su velik utjecaj na razvoj Broda na Savi kao trgovačkog i kulturnog središta. Pokazuje to i primjer djelovanja Hrvatskog pjevačkog društva "Davor" prigodom svečane posvete zastave u povodu 25. obljetnice Društva 1896. godine. Pripreme za posvetu i proslavu počele su dvije godine ranije, a u pripremama je sudjelovao i Bogdešić u funkciji arhivara. ${ }^{12}$ Izvori Bogdešića navode kao jednog od trojice „,izaslanika" koji su za zadaću imali pozvati biskupa Strossmayera na sudjelovanje u svečanosti (usp. Artuković, 2018: 175), a bio je zadužen i za prostor "pučke svečanosti“ nakon posvete (ibid. 186). Toga dana, 15. kolovoza 1896., u Brodu na Savi okupila su se brojna pjevačka društva iz cijele zemlje; Mitrovice, Petrovaradina, Zemuna, Vukovara, Đakova, Požege, Petrinje, Bjelovara, Zagreba i Karlovca te predstavnici

10 Usp. Učiteljski zbor Pučke škole Krapina, zapisnik sjednice br. 5, 23. 12. 1901.

11 Tajnik je bio Zefir Marac, članovi Odbora dr. Dobroslav Brlić, kapelan Martin pl. Kirchmayer, Rafael Merkadić, Ivan Kaparović i Dragutin Hruza, a članovi uže uprave, uz blagajnika Šandora Lorschyja, bili su Ivan Kaparović, Ivan Baumeister i Stjepan Benčević te Pero Bogdešić (usp. Artuković, 2018: 181).

12 „Izbor dvaju odbornika za arkivara - Izabrani P. Bogdešić i H. Krušac” (Zapisnik sjednice Hrvatskog pjevačkog društva "Davor", 20. lipnja 1895.). 
zborova iz Trsata, ${ }^{13}$ Sušaka, Mostara, Tuzle i Sarajeva (ibid. 193-194). Važnost navedenog događanja jest $u$ tome što su svi zborovi najprije zajedno otpjevali hrvatsku himnu, ali na način koji nije bio uobičajen:

„Himna se do tada izvodila na razne načine. Na 'Davorovoj' proslavi u Brodu započela je nova povijest hrvatske himne, jer se tada prvi put izvela, po preporuci Hrvatskoga pjevačkog saveza, jedinstveno, onako kako je kasnije izvođena kroz dugi vremenski period." (Ibid. 188)

Vrhunac proslave za Bogdešića je bio svečani govor koji je kao potpredsjednik „Davora“14 održao s posebnim zahvalama upućenim obitelji Brlić, a posebice Ivani Brlić Mažuranić - kumi zastave. Na proslavi je bio i njegov prijatelj, Požežanin Julije Kempf, koji je u svojoj knjizi Moja požeška sjećanja (1934.) ovjekovječio Bogdešićev govor:

„Uoči proslave posvete zastave priredili su svi pjevači i brodsko građanstvo sjajnu bakljadu i podoknicu u čast kume zastave Ivane Brlić-Mažuranić, supruge brodskog odvjetnika dr. Nace Brlića, predsjednika ‘Davora'. Kumu zastave, danas još živu proslavljenu hrvatsku spisateljicu, pozdravio je tajnik 'Davora' učitelj više građanske škole i moj dobri prijatelj i pobratim Pero Bogdešić kod bakljade oduševljenim patriotskim govorom. Zbog toga je taj poštenjačina za kratko vrijeme osjetio bič gordoga tadašnjega bana Khuena koji ga je dao premjestiti iz Broda u jedno selo! Bogdešić je pretrpio svoju inkviziciju, ali je poslije ponovno povraćen na svoje mjesto i ostao ljudina." (Kempf, 1996: 160)

Selo koje Kempf navodi jest Krapina. Od 1897. Petar Bogdešić je, prema dekretu, premješten u tamošnju Višu pučku školu. U Krapini se nastavio baviti kulturnim djelatnostima. Priključio se skupini entuzijasta koji su u Krapini osnovali podružnicu Hrvatskog planinarskog društva Zagreb za koju je i napisao i „društvena pravila“: ${ }^{15}$

"Od dulje vremena želili su prijatelji prirode, da se u Krapini osnuje podružnica hrvat. planinar. družtva u Zagrebu. - Ta je želja postala Bogu hvala i činom! - Na dan 19. travnja t. g. sazvan je u tu svrhu sastanak u veliku dvoranu gostione 〈Kruni〉. (...) Na sveobću želju (...) bude izabran za predsjednika podružnice, vrli naš predstojnik kotara, pogl. gosp. Žiga vitez Maravić. Za podpredsjednika bude jednoglasno izabran mjestni načelnik g. Vilibald Sluga, koji si je mnogo zasluga stekao poljepšavajući starodrevnu Krapinu i okolinu, za tajnika g. Gašo Vac, kr. kot. šumar, za blagajnika g. Franjo Kalečak, gradski blagajnik. Odbornici su ova p. n. gg.: Stj.

13 Petar i Marija Bogdešić u svojem su domu prilikom posvete zastave ugostili potpredsjednika i nekoliko članova Pjevačkog društva „Slavulj” iz Trsata (usp. Banovac, 1896).

14 Jednoglasno je izabran na sjednici 18. siječnja 1896. (Zapisnik sjednice Hrvatskog pjevačkog društva „Davor" br. 2, 18. siječnja 1896.).

15 Hrvatski planinar (1900), br. 5, god. III., Zagreb, str. 77. 
Vukovinski, Ante Turković, kr. kot. pristav, Lad. Hudjek, trgovac, Vjek. Šegulja, kr. gruntovničar, Stj. Meniga, ml. kavanar. Petar Bogdešić, učitelj više pučke škole. "16

Završetkom školske godine 1901./1902. Bogdešić je vraćen u službu u Brod na Savi. ${ }^{17}$ Ondje je radio u višoj pučkoj (građanskoj) te šegrtskoj školi: „Šegrtsku mladež obučavali su slijedeći učitelji i to (...) Bogdešić Petar, učitelj više pučke škole, risanje niži odio, trgov. knjigov. i pjevanje II. skup. Na tjedan 4 sata. “18 U Muzeju Brodskog Posavlja u Slavonskom Brodu sačuvana je fotografija učenika 7. razreda Više pučke škole s ravnateljem Lujom Franklom i razrednikom Perom Bogdešićem iz 1911. (prilog 2). U izvještaju iz 1916. navedeno je da je predavao matematiku, geometriju, zemljopis, risanje i krasopis. Osim toga, navedeno je da je bio knjižničar „Brlićeve knjižnice“. Riječ je o knjižnici koju je 1876. godine školi darovao Ignjat ml. Brlić, sin Ignjata Alojzija Brlića i brat Andrije Torkvata Brlića. ${ }^{19} 1915$. je kratko bio na supstituciji u višoj pučkoj školi u Novoj Gradiški te se potom ponovo vratio učiteljskoj službi u Brodu. ${ }^{20}$

Nakon povratka iz Krapine Bogdešić se sa suprugom Marijom²1 i djecom uključio u rad Hrvatskog dobrotvornog gospojinskog društva. ${ }^{22}$ Gospojinska su se društva $u$ to vrijeme osnivala i u drugim hrvatskim gradovima radi afirmacije žena $u$ političkom i obrazovnom sustavu, a mnogi su učitelji, pedagozi i političari aktivno sudjelovali u tom procesu (usp. Batina, 2018: 69). Kako su blagajnici Društva do 1925. godine bili isključivo muškarci, ${ }^{23}$ od 1905. blagajničku knjigu preuzima Petar Bogdešić i vodi je sve do 1916. godine. U tom su razdoblju predsjednice Društva bile Ivana Brlić-Mažuranić, Stanka Matić, Ema Mirković, Gizela Radosavljević, Karolina Heinzel i Ana Fridrich, supruge poznatih brodskih intelektualaca i aktivista. ${ }^{24}$

16 Hrvatski planinar (1899), br. 5, god. II., Zagreb, str. 76.

17 „2. Ravnatelj oglašuje uslijedivše promjene na zavodu. Vis. naredbom kr. zem. vlade od 15. kolovoza t. g. br. 12672 umirovljen je ravnatelj Nikola Kaurić na vlastitu molbu, a na ovaj zavod premješten je za ravnatelja Franjo Deželić dočim je učitelj više pučke škole Petar Bogdešić premješten u Brod, a umjesto njega pridijeljen je ovome zavodu na službovanje učitelj iz Lovčića gosp. August Petrović." (Učiteljski zbor Pučke škole Krapina, zapisnik sjednice 1. 9. 1902.)

18 Izvještaj... 1902.-1903. (1903), str. 70.

19 Usp. Izvještaj... 1902.-1903. (1903), str. 8.

20 Službeni glasnik, godina 1915., str. 13, 281.

21 Marija Bogdešić navedena je 1910. godine u Spomenici Hrvatskog dobrotvornog gospojinskog društva u Slavonskom Brodu (1935) kao jedna od članica Odbora Društva, no vrlo je vjerojatno u njegovu radu bila aktivna i prije i nakon 1910. godine.

22 Prema tekstu Ivana Medveda, Društvo službeno djeluje od 1895., kada su prihvaćena Pravila, no s djelovanjem je započelo već 1893. godine (usp. Medved, 2006).

23 „Nakon glavne skupštine 1925. godine blagajničke poslove preuzimaju gospođe“ (usp. Medved, 2006: 295).

24 Državni arhiv Slavonski Brod: Spomenica Hrvatskog dobrotvornog gospojinskog društva u Slavonskom Bro$d u$ (1935), str. 47. 
Uz to, Bogdešić je bio predsjednik i delegat skupštine Saveza hrvatskih učiteljskih društava. ${ }^{25}$ Za ravnatelja Više pučke škole u Brodu imenovan je 1918. godine, a nakon osnutka realne gimnazije i izgradnje nove zgrade 1922. godine predaje kao gimnazijski profesor do odlaska u mirovinu 1924. godine. ${ }^{26} \mathrm{O}$ tom je razdoblju i o „strogom učitelju Peri“ zabilježena anegdota:

„Kako je škola sagrađena na trgu, bila je već u početku izvrgnuta buci zbog velikog prometa, osobito za sajamskih dana kad su se i pred samom gimnazijskom zgradom nagomilali štandovi (tezge) različitih prodavača koji su hvalili svoju robu i vabili kupce. Jednog se sajamskog dana pojavio pred našom školom i prodavač svježih kuhanih kobasica i za vrijeme predavanja strogoga profesora Pere počeo vikati baš pred otvorenim prozorima našeg razreda: 'Aaaase kobase...!' Kako se neki od nas nisu mogli suzdržati od smijeha, došetao je profesor do nas noseći u ruci kredu i čvrknuo nas po glavi govoreći: 'Evo ti decimalna točka!' Tako je obično kažnjavao nemirne." (Berka, 1986: 736)

Petar Bogdešić također je poticao napredak prirodnih i prirodoslovnih znanosti. Naime, kako saznajemo iz izvora, nakon velikog potresa u Zagrebu 1880. godine osnovan je jedan od prvih odbora Jugoslavenske akademije znanosti i umjetnosti Odbor za opažanje potresnih pojava.

„Za predsjednika Odbora izabran je Josip Torbar koji je sastavio opširne Upute za opažanje potresnih pojava i posebni upitni arak, koji su u siječnju 1883. razaslani povjerenicima u sva veća mjesta. (...) Akademijin odbor angažirao se na prikupljanju podataka o učincima naših potresa počam od 1883. i njihovom proučavanju. Istraživanja su obuhvatila tadašnju Hrvatsku, Slavoniju i Dalmaciju te Bosnu i Hercegovinu. Podaci su objavljivani u Akademijinim 'Radovima' pod nazivom Izvješće potresnog odbora." (Skoko, 2002: 43, 44)

Poziv je tiskan i u Napretku 1883. godine pod naslovom „Uputa za opažanje potresnih pojava“27, pa je Bogdešić na temelju tog poziva sabirao podatke o potresima na području Broda i Krapine, a njegovi se prilozi „Potresnim izvješćima“ nalaze u Radovima Akademije za 1897., 1898. i 1902. godinu (usp. Kišpatić, 1898, 1898a, 1901).

Od početka svoje karijere nastojao je pridonijeti učiteljskoj struci. Pratio je stručnu literaturu i odazivao se na sve pozive koji su poticali napredak pedagogije i nastave. Svojim je financijskim prinosom, uz mnoge druge učitelje iz cijele zemlje, pridonio izgradnji Hrvatskog učiteljskog doma, ${ }^{28}$ historicističke građevine u centru

25 Usp. Posavska Hrvatska, 25. svibnja 1918.

26 U Godišnjem izvještaju Državne građanske škole u Slavonskom Brodu (1935) naveden je kao ravnatelj i dobrotvor škole.

27 Napredak 1883/9.

28 Donacija za Hrvatski učiteljski dom (usp. Napredak 1881/1, 1. siječnja) i „medicinski fakultet“ (usp. 
Zagreba koju je nastanio Hrvatski književno-pedagogijski zbor [HPKZ] - udruga učitelja i pedagoga osnovana 1871. godine. ${ }^{29}$

Uza sve navedeno, Bogdešić je bio i član Hrvatskog književnog društva sv. Jeronima (kasnije Društva sv. Ćirila i Metoda) i tamburaš HPD-a "Davor“ (usp. Toldi, 2018) te je radio na kišomjernoj stanici u Brodu. ${ }^{30}$

\section{Doprinos Petra Bogdešića hrvatskoj etnologiji i folkloristici}

Prvi su poticaji za sakupljanje tradicijskog, odnosno seoskog i pučkog gradiva krenuli od Maksimilijana Vrhovca 1813., kada je pozvao svećenstvo na zapisivanje folklornog sadržaja (usp. Čulinović-Konstantinović, 1979: 67). Nakon te inicijative kontinuirano se u kontekstu preporodnih ideja potiče sabiranje usmenoknjiževne, ali i druge jezične građe. Ilirac Ljudevit Gaj Vrhovčev je poziv pretisnuo u Danici ilirskoj 1837. godine i pozvao sve "pismene ljude“, a ne samo „duhovnike“, na prikupljanje usmenoknjiževnih oblika (usp. Batina, 2018: 41). Drugi istaknuti intelektualci skupljačkim su inicijativama pokušali dati svoj doprinos borbi za hrvatski jezik i nacionalni identitet. Jedan od takvih pojedinaca bio je pedagog Ferdo Hefele, koji je u svojem tekstu „Narodno cvieće ${ }^{\text {“31 }}$ pozvao na sabiranje nazivlja i uzoraka ženskog ručnog rada. U tekstu zahvaljuje nekolicini učitelja koji su poslali uzorke ručnog rada za zbirku Hrvatskog književno-pedagoškog zbora, među ostalima i Petru Bogdešiću. Detaljnije izvješće o tome navedeno je u „Vjestniku“ Napretka iz 1890. godine:

„G. Bogdešić Peroslav, učitelj u Petrovuselu kod Nove Gradiške, poklonio je pedag. sboru takodjer sbirku narodnoga veziva, a uz to nešto čipkanja, da ih sbor upotrebi. Naveo je i neke izraze, koje narod upotrebljava za pojedine vrsti rada i komada. Ti izrazi jesu: jabučice, grane, uzruče, podveza, vezak ili vitak, skut, ušivalo, split, šupak ili pušak, pola, oplećak. “32

Hrvatski pedagoško-književni zbor sačuvao je pristiglu tekstilnu (i drugu) građu te je ona postala dio prvog stalnog postava Hrvatskog školskog muzeja otvorenog u novoj zgradi Hrvatskog učiteljskog doma. U katalogu prvog stalnog postava Muzeja navedeno je da se zbirka uzoraka nalazila u drugoj sobi u dijelu Narodne nošnje i uzorci ženskih narodnih radnja:

Narodne novine 1892., 11. studenoga).

${ }^{29} \mathrm{HPKZ}$ je izdavao časopis Napredak, koji je bio glavno glasilo učiteljske struke čitave zemlje. U Napret$k u$ se poticao rad učitelja, donosile su se novosti, objavljivali pedagoški tekstovi i eseji te pozivi za kulturno-prosvjetni rad. Niz radova bio je na temu važnosti zorne obuke, pa se poticalo prepariranje životinja koje bi služile u prirodoslovnoj obuci, sakupljanje tekstilne građe i drugog ručnog rada, dok su moralnoj obuci trebale pridonijeti vjerske i tradicijske poslovice i drugi oblici usmene književnosti, a sve s posebnim naglaskom na sakupljanje lokalne građe - iz mjesta škole i njezine okolice.

30 Usp. Izvještaj o vodenim talozima, vodostajima i količinama vode za 1926 god. (1931).

31 Napredak $1886 / 34$.

32 Napredak $1890 / 3,47$. str. 
„94. Uzorci narodnog veziva. 18 ploča s 253 uzorka. Sabrali i poklonili Vinko Bek, učitelj u Bukevju, Amalija Markulinova, učiteljica u Blinji, Peroslav Bogdešić, učitelj u Dragovcima i Josip Strašek, u Oborovu. ${ }^{\text {“33 }}$

Paralelno s različitim pozivima pojavila se i potreba za osnivanjem institucija koje bi vodile i poticale kulturno-znanstveni rad te objavljivale prikupljenu jezičnu građu. Ta je zamisao dovela do osnivanja Matice ilirske 1842. godine. Bogatom izdavačkom djelatnošću nastavila je poticati hrvatsko književno stvaralaštvo i druge preporodne aktivnosti uključujući i usmeno književno stvaralaštvo:

„Sredinom 1876. godine Matica je hrvatska, a na poticaj Mihovila Pavlinovića, odlučila da oglasi poziv za sabiranje hrvatskih narodnih pjesama. Godinu i pol nakon toga, u studenom 1877. pojavio se u svim hrvatskim novinama tekst Poziv za sabiranje hrvatskih narodnih pjesama. U pozivu je, između ostalog, pisalo: Svim rodoljubima hrvatskim!“ (Mimica, 2009: 135)

Potaknut Matičinim Pozivom, Petar Bogdešić do 1885. godine sakupio je i Matici hrvatskoj predao narodne pjesme zabilježene u Dragovcima, u kojima je tada službovao. ${ }^{34} \mathrm{U}$ Poziou se poticalo zapisivače na bilježenje imena i statusa kazivača u kontekstu izvedbe pjesama. Bogdešić je u popratnom pismu Matici zabilježio imena svojih triju kazivačica iz Dragovaca - Margite Žebčević, Jule Gušić i Janje Dosegović, ali o njima nije zabilježio druge podatke. Zanimljiv je podatak da je Bogdešić svojoj kazivačici Margiti Žebčević morao „platiti“ kazivanje:

„Prva mi je kazala ih preko 40, a tad reče da više ne zna, ali u istinu više nije htjela ili se česa bojeći ne htjede, stoga joj rekoh kupiti maramu, a ona mi kaza još kojih 30 pjesama. ${ }^{\prime 35}$

U pismu upućenom Matici Bogdešić zabilježene je pjesme žanrovski razdijelio prema kontekstu izvođenja na: 1) „Ženske pjesme većeg sadržaja koje se pjevaju u kolu“ (64 lirske, većinom deseteračke pjesme); 2) Pjesme koje se tiču „osvajanja Bosne i vojničkog života“ (75 epskih desetaračkih i osmeračkih pjesama); 3) „Pjesme dječaka koje običavaju pjevati stojeći za kolom, ili inače pri raznih sgodah“ (213 pjesama u dvostrukim četrnaestercima); 4) „Poskočice koje se pjevaju poput onih u I. odsjeku, u kolu, ali samo igrajući uz tamburu, gusle, dude ili dvojnice“ (788 dvostruko rimovanih deseteraca - bećaraca). Folkloristima i istraživačima usmene književnosti ime Petra Bogdešića nije nepoznato jer je dio pjesama koje je sakupio u

33 Hrvatski školski muzej. Njegov postanak i uređenje. U Zagrebu 1902. Nakladom „Hrv. pedagoško-književnog zbora". Tisak C. Albrechta (Jos. Wittasek), 81. str.

34 Sbirka hrvatskih narodnih pjesama Matici je poslana 28. travnja 1885., a 1952. Matica je svoje zbirke dala Akademiji. Pjesme su danas pohranjene u arhivu Odsjeka za etnologiju Hrvatske akademije znanosti i umjetnosti pod signaturom MH 57.

35 P. Bogdešić (1885), Zbirka korespondencije OE HAZU (sign. K.MH. 13, str. 2). 
Dragovcima tiskan 1929. godine u Matičinu izdanju Hrvatske narodne pjesme, a 2005. godine u Slavonskim pismicama Martina Grgurovca. ${ }^{36}$ Iz nekoliko komentara u popratnom pismu koje je Bogdešić poslao uz pjesme moguće je dobiti uvid u povijest i život u Dragovcima, no opširniji kontekst pjesmama Bogdešić je dao četrnaest godina kasnije odazivom na prikupljanje građe o narodnom životu na temelju Radićeve Osnove.

Iako je ideja postojala od 1861. godine, Jugoslavenska akademija znanosti i umjetnosti osnovana je 1866. godine, a njezin Odbor za sabiranje spomenika tradicionalne literature 1888. godine. Ideja o pokretanju zbornika u kojemu bi se tiskali svi prinosi o (južno)slavenskom narodnom životu realizirala se početkom 1896. godine objavljivanjem Zbornika za narodni život i običaje južnih Slavena pod uredništvom Ivana Milčetića. Od 2. broja uredništvo je preuzeo Antun Radić te je ostao na tome mjestu sljedećih pet godina (usp. Batina, 2018: 138). Kako bi dodatno potaknuo i usmjerio sakupljanje građe kakvu želi objavljivati u Zborniku, Radić je sastavio Osnovu za sabiranje i proučavanje građe o narodnom životu i objavio je u drugom broju Zbornika 1897. godine. Upravo je Osnova bila temeljni Radićev „programatski dokument“ koji ga neupitno čini utemeljiteljem hrvatske etnologije (usp. Muraj, 1984: 31). Pitanja su u naputku strukturirana trodijelno (I. Priroda (narav) oko čovjeka; Tjelesni ustroj naroda; Jezik; II. Materijalna kultura; III. Duševna kultura) kako bi se dobio holistički etnografski opis na lokalnom idiomu. Pozivu su se odazvali mnogi učitelji uključujući i Petra Bogdešića, koji je do 1899. napisao etnografski prikaz narodnog života i običaja sela Dragovci. ${ }^{37}$ Život i narodni običaji u selu Dragovcima, župa Nova Kapela, kotar Novogradiški i po nješto okoline počinje opisom mjesta, nakon čega slijedi povijesni prikaz nastanka mjesta i doseljavanja domaćeg stanovništva. Opsežan dio posvećen je ženskom odijevanju i životnim običajima, posebice svadbi, a nešto manje godišnjim običajima. Za Bogdešića je narodna nošnja važan aspekt materijalne kulture te joj posvećuje deset stranica rukopisa s posebnim naglaskom na žensko odijevanje. Slijede godišnji običaji - crkveni god, svetkovanje i slavljenje krsnog imena (godovno). Kod ta dva (odnosno tri ${ }^{38}$ ) običaja Bogdešić detaljno opisuje tko dolazi, kako se slavi te kako su se upravo na takvim događanjima gradili odnosi među ljudima:

„Prijatelji su se svakom sgodom međusobno štovali i podupirali, u svakoj potrebi jedan na drugoga se oslonio i obratio. Ako znanac nebi znancu posjete povratio, držalo se je ne samo od novoga znanca za preveliku uvredu, nego su i drugi ga za to prekoravali. - Ovaj način sklapanja prijateljstva imao je u ono vrijeme, gđe si mogao

36 Osim navedenih, na Bogdešićeve stihove referirali su se i Botica, 2013; Rončević, 2013; Delić, 2014; Batina, 2018.

${ }_{37}$ Rukopis nije objavljen u Zborniku, a čuva se u arhivu Odsjeka za etnologiju pod signaturom SZ 92.

38 U opisu godovna Bogdešić napominje da je katoličko stanovništvo slavilo krsno ime domaćina, a pravoslavno krsno ime zaštitnika kuće (Bogdešić (1899), SZ 92, str. 19). 
proputovati po njekoliko sela, a da se nećeš namjeriti na gostionu, od prevelike važnosti. Svaki se je držao poslovice: 'Gradi si kuću u svakom selu!'“39

Osim pozitivnih međuljudskih odnosa na proslavama crkvenih i drugih godova, Bogdešić je opisao i mogućnost (ne)pozivanja na god koje uzrokuje negativan stav kod domaćina i/ili gosta. Od svakodnevnih običaja dodatno opisuje sijelo i prelo te klanje krmaka. U opisima svinjokolje ponovo se iščitavaju podaci o međuljudskim odnosima: „Bolji prijatelji ne bi htjeli ni pošto u isti dan obojica klati. " ${ }^{40}$ Nastavljajući, opisuje sve detalje vezane uz druženja oko klanja krmaka (što se jede i pije, kako se ljudi zabavljaju itd.), a vrlo malo piše o samom postupku svinjokolje. Odnos s bližnjima također je važan aspekt opisa smrti i pogrebnih običaja:

„Na naricanje se pazi mnogo, da ne bude po njihovom shvaćanju prazno. Ako nije nikoga od roda, ili baš i ako ga je, pak se ustručava jaukati na glas, ili ne zna lijepo, tad se prihvati posla ona baka, koja je bolesnika čuvala. Dadu joj tikvicu rakije, a baka misli na svojega kojeg pokojnika 'te slaže i prilaže' za ovoga tako dugo, dok god je na odru, pa i u sprovodu. ${ }^{\prime 41}$

Nakon završetka opisa karmina slijedi opis ženidbe. Odlomci Ženidba ${ }^{42}$ i Svatovanje $^{43}$ na četrdeset rukopisnih stranica čine polovicu Bogdešićeva rukopisa. U tim se opisima posebno ističu dijelovi u kojima se govori o odnosu udane žene prema određenom običaju ili životnoj situaciji (poglavlja Još njekoji običaji i Udovica):

„Po smrti suprugovoj ne smije se udovica udavati po drugi puta barem za po godine. Davno prije, smjela se je zaručiti odmah drugi dan po 'pogrebu' (ukopu), nije bilo zamjerke. Za drugoga supruga može ponesti sve što je njeno bilo, a i muževu robu, ako je za njega bila udana barem godinu dana. Inače roba pripada kući, jer je iz kuće i kupljena. Svadbene troškove daje kuća, ali dakako ovi su uvijek u daleko manjoj mjeri, jer se udovički svatovi imadu obaviti bez ikakovih ceremonija samo za jedan dan. Stoga i djevojci, koja je obavila svadbu za jedan dan, vele, da je imala udovičke svatove. Djeca mogu ići s majkom, a mogu ostati u kući. (...) Ako vjerenik ostavi vjerenicu, ili obratno, nije velika sramota. Nu ostavi li vjerenik to od darova ne dobiva nazad baš ništa, a ostavi li vjerenica, vraća sve, ako prem vrlo teško ide. Priženi li se momak u kuću djevojci, a ova je sama, dobije kuća ime domazetovo, ako su pako još njeni roditelji živi, to domazet poprimi obiteljsko ime. ${ }^{\prime 44}$

Iako Bogdešićev etnografski zapis ne slijedi naputak Radićeve Osnove, on pred-

\footnotetext{
39 Bogdešić (1899), SZ 92, str. 17, 18.

40 Bogdešić (1899), SZ 92, str. 34.

41 Bogdešić (1899), SZ 92, str. 37.

42 Potpoglavlja Ženidbe: Zaruci, Kudnja, Sabatnica, Kupovanje robe, Gotovo, Riječ i torba, Ugovori, Miraz.

43 Potpoglavlja Svatovanja: Doček, U novom domu, Večera, Snašino darivanje, Ložnica, Prvi dan u kući, Pirnice ili pirovi i rastanak, Prva nedjelja u novom domu, Babinje.

44 Bogdešić (1899), SZ 92, str. 80.
} 
stavlja vrijedno svjedočanstvo o tradicijskoj kulturi, životu i običajima s kraja 19. stoljeća u selu Dragovci te na širem području zapadne Slavonije, koje je inače manje zastupljeno u etnografskim zapisima iz toga vremena. Bogdešićevi etnografski opisi svakodnevice nisu samo činjenični suhoparni navodi nego su to opisi obogaćeni jezičnim izrazima i frazama te usmenim oblicima i dijalozima koji na živopisan način kontekstualiziraju obiteljske i susjedske odnose i relacije u određenom vremenu i prostoru.

\section{Zaključne misli}

Petar Bogdešić bio je pripadnik učiteljskog staleža i sloja inteligencije koji je, osim obrazovno-odgojnih zadataka, imao potrebu pridonijeti i sveukupnom napretku kroz kulturni, društveni pa i politički angažman. Unatoč materijalnim ograničenjima, učitelji su odabirom svojega poziva bili istaknuti članovi društva, odnosno zajednice, koja je od njih imala i određena očekivanja. Petar Bogdešić, sudeći prema dostupnim biografskim podatcima, svojim marljivim, strogim i pedantnim učiteljskim pristupom te angažmanom na području kulturnih i društvenih djelatnosti, a posebice suradnjom s Maticom hrvatskom i Jugoslavenskom akademijom na poslu prikupljanja etnografske i folklorističke građe, znatno je pridonio razvoju kulturne i prosvjetne djelatnosti te očuvanju tradicijske kulture, života i običaja na području zapadne Slavonije na prijelazu 19. i 20. stoljeća, odnosno u prvoj trećini 20. stoljeća.

\section{Literatura}

Artuković, Mato (2018), Proslava posvete Zastave i 25. godišnjice Hrvatskoga pjevačkog društva "Davor" 1896. Scrinia Slavonica 18, Slavonski Brod: Hrvatski institut za povijest, Podružnica za povijest Slavonije, Srijema i Baranje, str. 175-233. Batina, Klementina (2018), Aspekti ženskog autorstva u ranoj hrvatskoj etnologiji i folkloristici, Zbornik za narodni život i običaje, knj. 60, Zagreb: Hrvatska akademija znanosti i umjetnosti.

Batinić, Štefka, Gaćina Škalamera, Sonja (2009), Učiteljice i učitelji u Hrvatskoj 1849.2009., Zagreb: Hrvatski školski muzej.

Berka, Josip (1986), Počeci gimnazije u Slavonskom Brodu, Marulić: hrvatska književna revija; časopis za knjižeonost i kulturu, Br. 6, studeni - prosinac, god. XIX. Zagreb: Hrvatsko književno društvo sv. Ćirila i Metoda, str. 735-737.

Botica, Stipe (2013), Povijest hrvatske usmene književnosti, Zagreb: Školska knjiga.

Božić, Petar (1952), Učitelji i učiteljice, koji su maturirali odnosno diplomirali na Učiteljskoj školi u Petrinji, Spomenica Učiteljske škole u Petrinji 1862.-1952, Zagreb: Tisak Grafičke škole u Zagrebu, str. 37-72. 
Čulinović-Konstantinović, Vesna (1979), Historijski prikaz etnoloških istraživanja i interesa za narodnu kulturu u Hrvatskoj. Etnološka tribina 2, Zagreb: Hrvatsko etnološko društvo, str. 67-88.

Delić, Simona (2014), Slavonske inačice pjesme o djevojci-ratnici u hrvatskoj usmenoj tradiciji u komparativnom kontekstu: književno-antropološki pristup, Scrinia Slavonica 14, Slavonski Brod: Hrvatski institut za povijest - Podružnica za povijest Slavonije, Srijema i Baranje, str. 79-106.

Grgurovac, Martin (2005), Slavonske pismice: 10.000 bećaraca, drumaraca, svatovaca..., Vinkovci: Privlačica.

Jonjić, Tomislav (2015), Ivo Pilar kao politički ideolog, doktorska radnja, Zagreb: Hrvatski studiji.

Kempf, Julije ((1934) pretisak 1996), Moja požeška sjećanja. Požega: Matica hrvatska Ogranak Požega.

Kišpatić, Mijo (1898), Petnajsto potresno izvješće: za god. 1897., Rad JAZU, Matematičko-prirodoslovni razredi, Knj. 25, Zagreb: Hrvatska akademija znanosti i umjetnosti, str. 175-198.

Kišpatić, Mijo (1898a), Šesnajsto potresno izvješće: za godinu 1898., Rad JAZU, Matematičko-prirodoslovni razredi, Knj. 26, Zagreb: Hrvatska akademija znanosti i umjetnosti, str. 80-124.

Kišpatić, Mijo (1902), Devetnaesto potresno izvješće: za godinu 1902., Rad JAZU, Matematičko-prirodoslovni razredi, Knj. 32, Zagreb: Hrvatska akademija znanosti i umjetnosti, str. 140-177.

Medved, Ivan (2006), Hrvatsko dobrotvorno gospojinsko društvo u Brodu na Savi 1895.-1941., Scrinia Slavonica 6, Slavonski Brod: Hrvatski institut za povijest, Podružnica za povijest Slavonije, Srijema i Baranje, str. 290-304.

Mimica, Ivan (2009), Usmeno pjesništvo porječja Krke u knjigama velike edicije Hrvatske narodne pjesme Matice hrvatske. Godišnjak Titius, god. 2, br. 2, Split: Znanstveni projekt TITIUS, Filozofski fakultet u Splitu, str. 135-150.

Muraj, Aleksandra (1984), Teorijsko-metodološke zamisli Antuna Radića i njihov utjecaj na etnološki rad u Hrvatskoj, Etnološka tribina 6-7, Zagreb: Hrvatsko etnološko društvo, str. 31-36.

Radić, Antun (1897), Osnova za sabiranje i proučavanje građe o narodnom životu, Zbornik za narodni život i običaje Južnih Slavena, knj. 2, Zagreb: Hrvatska akademija znanosti i umjetnosti, str. 1-88.

Rončević, Ivan (2013), Bećarac - dvostruko rimovani deseterac kao kulturni izričaj Istočne Hrvatske, doktorska radnja, Beč: Universität Wien.

Skoko, Dragutin (2002), Kišpatićev doprinos seizmologiji, Spomenica preminulim akademicima: Mijo Kišpatić: 1851.-1926. Zagreb: Hrvatska akademija znanosti i umjetnosti, str. 43-62. 
Toldi, Zvonimir (2018), Kad udara sedam tamburaša, 101 brodska priča, Slavonski Brod: Muzej Brodskog Posavlja, str. 245-247.

\section{Internetski izvori}

Family search, Matične knjige rođenih, umrlih i vjenčanih Slavonski Brod, www. familysearch.org (posljednji put posjećeno 11. 11. 2020.)

\section{Arhivski izvori}

Arhiv Odsjeka za etnologiju Hrvatske akademije znanosti i umjetnosti: Rukopis iz kolekcije Stare zbirke (SZ): Bogdešić, Pero (1899), Život i narodni običaji u selu Dragovcima, župa Nova Kapela, kotar Novogradiški i po nješto iz okoline [SZ 92].

Arhiv Odsjeka za etnologiju Hrvatske akademije znanosti i umjetnosti: Rukopis iz kolekcije Matice hrvatske (MH), Bogdešić, Petar (1885), Sbirka hrvatskih narodnih pjesama [MH 57].

Arhiv Odsjeka za etnologiju Hrvatske akademije znanosti i umjetnosti: Rukopis iz kolekcije Matice hrvatske (MH), Bogdešić, Petar (1885a), Pismo autora Matici [K.MH.13].

Državni arhiv Slavonski Brod: Blagajnička knjiga Hrv. dobr. gosp. druš. Slav. Brod. (1938).

Državni arhiv Slavonski Brod: Zapisnici sjednica Hrvatskoga pjevačkog društva „Davor" u Brodu na Savi (1893-1925).

Državni arhiv Slavonski Brod: Spomenica Hrvatskog dobrotvornog gospojinskog društva u Slavonskom Brodu, (1935).

Državni arhiv Varaždin - Arhivski sabirni centar Krapina: Učiteljski zbor Pučke škole Krapina; Zajedničke sjednice više i niže pučke škole (1902.); Zapisnik br. 5, 23. 12. 1901.

Državni arhiv Varaždin - Arhivski sabirni centar Krapina: Učiteljski zbor Pučke škole Krapina; Zajedničke sjednice više i niže pučke škole (1902.); Zapisnik br. 6, 4. 1. 1902.

Državni arhiv Varaždin - Arhivski sabirni centar Krapina: Učiteljski zbor Pučke škole Krapina; Zajedničke sjednice više i niže pučke škole (1902.); Zapisnik br. 1, 1. 9. 1902.

Gradska knjižnica Slavonski Brod, Zavičajna zbirka: Jubilarno izvješće Državne realne gimnazije u Brodu na Savi 1918.-1943. Slavonski Brod: Knjigotiskara V. Buk.

Gradska knjižnica Slavonski Brod, Zavičajna zbirka: Državna građanska škola u Slavonskom Brodu (1935), Godišnji Izvještaj za škol. god. 1934-35. (1935), Slavonski Brod: Tiskara H. Schulman.

Hrvatski državni arhiv: HR-HDA-1567. Matica hrvatska (MH). Zaklade. Zakladni list 20, kut. 80 
Hrvatski planinarski savez: Hrvatski planinar (1899), br. 5, god. II., Zagreb, str. 75-76. (www.hps.hr)

Hrvatski planinarski savez: Hrvatski planinar (1900), br. 5, god. III., Zagreb, str. 76-79. (www.hps.hr)

Hrvatski školski muzej: Hrvatski školski muzej. Njegov postanak i uređenje, 1902., Zagreb: Nakladom „Hrv. pedagoško-književnog zbora“, Tisak C. Albrechta (Jos. Wittasek).

Hrvatski školski muzej: Službeni glasnik kr. hrv.-slav.-dalm. zemaljske vlade odjela za bogoštovje i nastavu, godina 1884., Zagreb: Tisak Kr. zemaljske tiskare.

Hrvatski školski muzej: Službeni glasnik kr. hrv.-slav.-dalm. zemaljske vlade odjela za bogoštovje i nastavu, godina 1915., Zagreb: Tisak Kr. zemaljske tiskare.

Kraljevina Jugoslavija, Ministarstvo građevina, Hidrotehničko odelenje - Beograd (1931), Izvještaj o vodenim talozima, vodostajima i količinama vode za 1926 god., Sarajevo: Državna štamparija.

Muzej Brodskog Posavlja: Izvještaj više pučke škole realnog smjera i s njim spojene dječačke, te šegrtske škole u Brodu na Savi koncem 1902.-1903. (1903), Slavonski Brod: Tisak H. Schulmanna.

Muzej Brodskog Posavlja: MBP-32312 (1911), VII. razred više pučke škole u Brodu na Savi, direktor Lujo Frankl, razrednik Pero Bogdešić (prilog 2.).

Nacionalna i sveučilišna knjižnica: (22. kolovoza 1896.) Posveta barjaka hrv. pjev. družtva „Davor" u Brodu, Banovac.

Nacionalna i sveučilišna knjižnica: (1. siječnja 1881.) Izkaz p. n. gg. prinosnika za gradnju hrv. učit. doma u Zagrebu, Napredak, 1881/1.

Nacionalna i sveučilišna knjižnica: Uputa za opažanje potresnih pojava, Napredak, 1883/9.

Nacionalna i sveučilišna knjižnica: Hefele, Ferdo (1. prosinca 1886.), Narodno cvieće, Napredak, 1886/34.

Nacionalna i sveučilišna knjižnica: (20. siječnja 1890.) Vjestnik, Napredak, 1890/3.

Nacionalna i sveučilišna knjižnica: Narodne novine (11. studenog 1892.).

Nacionalna i sveučilišna knjižnica: Proljetna skupština učiteljskog društva „Ivan Filipović" za grad Brod i kotar brodski, Posavska Hrvatska, list za politiku, pouku i gospodarstvo (1907-1918), br. 21, god. XII, dne 25. svibnja 1918. 


\section{Prilozi}

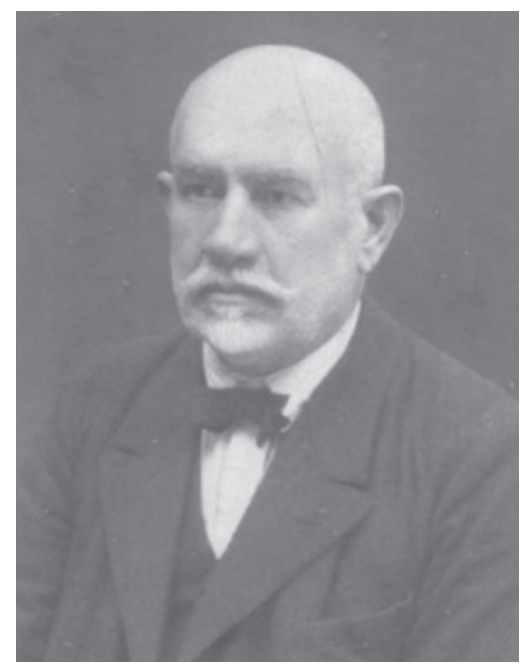

Prilog 1. Petar Bogdešić, fotografija iz Spomenice Hrvatskog dobrotvornog gospojinskog društva u Slavonskom Brodu (1935.)

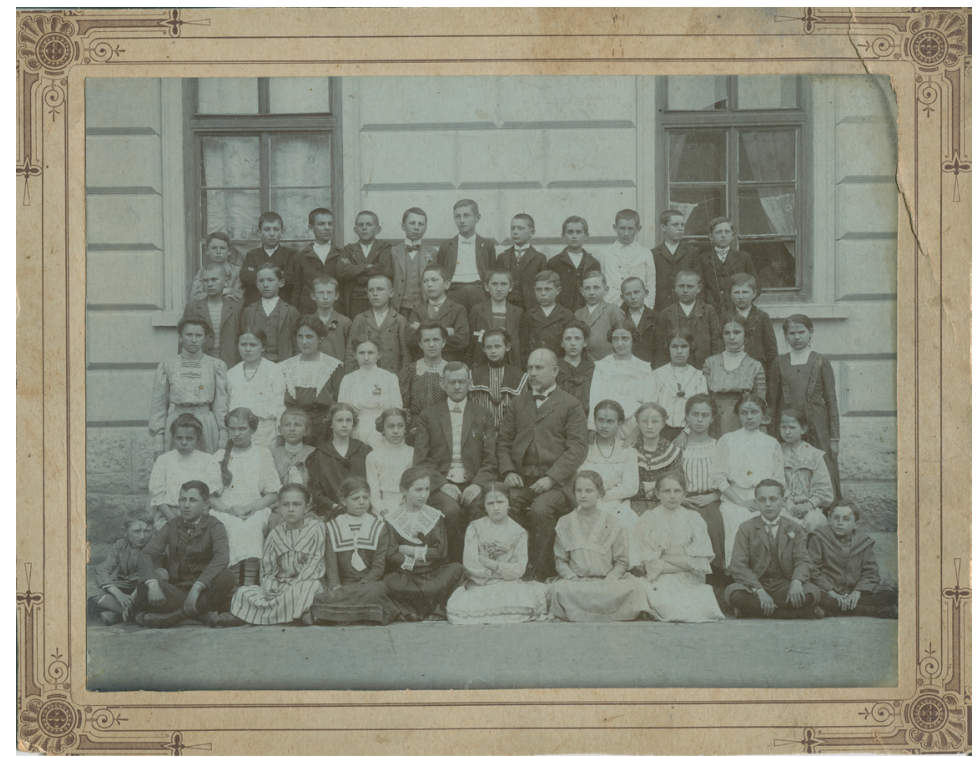

Prilog 2. VII. razred više pučke škole u Brodu na Savi, direktor Lujo Frankl, razrednik Pero Bogdešić (1911.), MBP-32312 (Muzej Brodskog Posavlja) 


\section{Petar Bogdešić (1863-1934) - Slavonian Teacher and Ethnographic Folklorist Writer \\ Summary}

Based on the analysis of available biographic data on Petar Bogdešić, his collaboration with national institutions in collecting ethnographic and folklorist writings, and his involvement in cultural and social events taking place in his places of work as teacher - in the period between 1882 and his retirement in 1924 (Dragovci; Brod na Savi; Krapina), the paper intends to shed more light on the fact that teachers as educational workers were actively involved in the process of shaping and enhancing national identity. This involvement was reflected in keeping record of the material, non-material and spiritual cultural heritage of the Croatian rural life based on instructions obtained and in collaboration with editors of publications that included the collected materials. Biographic data on Petar Bogdešić both as teacher and as active educational and cultural worker have been reconstructed on the basis of studies of the available sources. His etnographic and folklorist opus has, however, been reconstructed on the basis of the comparative analysis of two manuscripts, which are in in custody of the archives of the Division of Ethnology of the Croatian Academy of Sciences and Arts in Zagreb.

Keywords: Petar Bogdešić; teacher; Dragovci; Brod na Savi; ethnographic writings; folk poems.

Katarina Dimšić, mag. ethnol. et cult. anthrop.; mag. museol.

Hrvatski sabor kulture

Marjanska 12a, 31000 Osijek

katarina.dimsic@gmail.com 